\title{
Perbandingan Quadratic Discriminant Analysis dan Support Vector Machine untuk Klasifikasi Tutupan Lahan di DKI Jakarta
}

\author{
Kamaluddin Junianto Dimas*, Rahma Anisa*, Itasia Dina Sulvianti* \\ *Departemen Statistika Institut Pertanian Bogor
}

\begin{abstract}
Abstrak-DKI Jakarta is a center of government as well as economy and business of Indonesia, thus development projects in Jakarta continue every year. Therefore, monitoring for land use has to be improved in accordance to DKI Jakarta Spatial Planning. The attempt needs to be supported by continuous data availability regarding land cover condition in Jakarta. The aforementioned data collecting process become easier due to remote sensing technology development. Remote sensing technology can be utilized for analyzing the size of land use area by using classification analysis. It has been found that the level of accuracy depends on the type of classification method and number of training data. This research evaluated the level of overall accuracy, sensitivity, and specificity of Quadratic Discriminant Analysis (QDA) and Support Vector Machine (SVM) along with number of data training used in classifying Jakarta land cover in 2017. The results showed that in both methods, the variance of all the aforementioned criteria were getting smaller along with the increasing number of training data. QDA and SVM had similar performance based on overall accuracy and specificity. However, SVM was better than QDA on sensitivity.
\end{abstract}

Kata kunci-klasifikasi; diskriminan; jakarta; support vector machine; tutupan lahan

\section{PENDAHULUAN}

\section{A. Latar Belakang}

Banyaknya penduduk DKI Jakarta tahun 2016 berdasarkan data Badan Pusat Statistik Provinsi DKI Jakarta (2017) mencapai 10 juta jiwa dengan laju pertumbuhan penduduk per tahun sebesar $1.07 \%$. Pertambahan banyaknya penduduk akan diikuti peningkatan kegiatan pembangunan di Jakarta. Dalam rangka menata kegiatan pembangunan di kota untuk menjaga interaksi yang harmonis dan seimbang antar manusia dengan lingkungan, salah satu upaya pemerintah adalah mengeluarkan peraturan daerah tentang Rencana Tata Ruang Wilayah (RTRW) yang berlaku untuk jangka waktu 20 tahun dan ditinjau kembali setiap 5 tahun. Peraturan tersebut mengatur penyediaan lahan untuk kegiatan pembangunan serta penyediaan Ruang Terbuka Hijau (RTH) di wilayah kota.

Berdasarkan data Katadata (2017), pada Januari 2017, proporsi luas Ruang Terbuka Hijau (RTH) di Jakarta mencapai sekitar $9.98 \%$ dari total luas DKI Jakarta. RTH tersebut terdiri atas taman kota, taman lingkungan, taman interaktif, dan jalur hijau. Undang-Undang Nomor 26 Tahun 2007 menetapkan penyediaan RTH minimal $30 \%$ dari luas wilayah kota. Oleh karena itu, perlunya peningkatan pengawasan terhadap penggunaan lahan agar penggunaannya tetap sesuai dengan RTRW. Usaha tersebut perlu ditunjang dengan tersedianya data secara kontinu mengenai kondisi tutupan lahan di kota.

Perkembangan ilmu pengetahuan dan teknologi memudahkan proses pengumpulan data mengenai kondisi tutupan lahan dengan teknologi pengindraan jauh. Teknologi pengindraan jauh dapat dimanfaatkan untuk pemetaan tutupan lahan dengan analisis klasifikasi. Berbagai studi pada klasifikasi tutupan lahan telah dilakukan untuk mengetahui tingkat akurasi yang dihasilkan setiap metode serta faktor-faktor yang mempengaruhi. Muhammad (2014) melakukan sebuah studi untuk mengkaji performa beberapa metode klasifikasi terhadap tingkat keragaman tutupan lahan yang berbeda. Hasil studi Muhammad menunjukkan bahwa metode klasifkasi Maximum Likelihood atau yang dikenal sebagai Quadratic Discriminant Analysis (QDA) menghasilkan tingkat akurasi paling tinggi untuk setiap tingkat keragaman tutupan 
lahan. Noi and Kappas (2018) melakukan studi untuk mengkaji tingkat akurasi beberapa metode klasifikasi nonparametrik dengan faktor berupa banyaknya data training yang digunakan dan data training yang seimbang dan tidak seimbang. Hasil studi tersebut menunjukkan bahwa metode klasifikasi Support Vector Machine (SVM) menghasilkan tingkat akurasi paling tinggi untuk setiap banyaknya dan kondisi data training. Berdasarkan penelitian-penelitian tersebut, setiap metode klasifikasi dapat menghasilkan tingkat akurasi yang berbeda. Akurasi ini pun juga bergantung pada data training dan tingkat keragaman pada citra yang dikaji.

Penelitian ini mengkaji tingkat akurasi dari metode QDA dan SVM untuk klasifikasi kondisi tutupan lahan vegetasi dan nonvegetasi di DKI Jakarta tahun 2017. Selain itu, tingkat akurasi dikaji berdasarkan banyaknya data training yang digunakan.

\section{B. Tujuan}

Penelitian ini bertujuan :

1) Membandingkan metode Quadratic Discriminant Analysis dan Support Vector Machine untuk klasifikasi tutupan lahan vegetasi dan nonvegetasi di provinsi DKI Jakarta tahun 2017.

2) Melihat pengaruh ukuran data training terhadap kinerja dari masing-masing metode.

\section{TINJAUAN PUSTAKA}

\section{A. Quadratic Discriminant Analysis}

Metode Quadratic Discriminant Analysis (QDA) dikenal juga sebagai metode Maximum Likelihood Classification (MLC) (Richards (2012)). Metode ini umum digunakan dalam pengolahan data citra pengindraan jauh. Metode ini dikembangkan berdasarkan teorema Bayes, dimana peluang piksel akan diklasifikasi sebagai kelas ke-i berdasarkan nilai $\mathbf{x}$ dinyatakan sebagai berikut:

$$
p\left(y_{i} \mid \mathbf{x}\right)=\frac{p\left(y_{i}\right) f_{i}(\mathbf{x})}{\sum_{i=1}^{2} p\left(y_{i}\right) f_{i}(\mathbf{x})}, i=1,2
$$

dengan:

$y_{i} \quad:$ kelas ke- $i$

$\mathbf{x} \quad$ : vektor nilai piksel

$p\left(y_{i}\right)$ : peluang terpilihnya piksel kelas ke- $i$ secara acak dari populasi

$f_{i}(\mathbf{x})$ : fungsi kepekatan $\mathbf{x}$ untuk piksel yang berasal dari kelas ke- $i$

$\mathbf{x}$ dianggap menyebar mengikuti sebaran normal ganda sehingga:

$f_{i}(\mathbf{x})=\frac{1}{(2 \pi)^{\frac{p}{2}}\left|\boldsymbol{\Sigma}_{i}\right|^{\frac{1}{2}}} \exp \left(-\frac{1}{2}\left(\mathbf{x}-\boldsymbol{\mu}_{i}\right)^{T} \boldsymbol{\Sigma}_{i}^{-1}\left(\mathbf{x}-\boldsymbol{\mu}_{i}\right)\right)$

dengan:

$p \quad$ : dimensi $\mathbf{x}$

$\boldsymbol{\Sigma}_{i} \quad$ : matriks ragam peragam kelas ke- $i$

$\boldsymbol{\mu}_{i}$ : vektor nilai tengah kelas ke- $i$

Jika fungsi log diterapkan terhadap persamaan (1) dan nilai penyebut dianggap sama untuk setiap $p\left(y_{i} \mid \mathbf{x}\right)$, maka:

$$
\begin{aligned}
g_{i}(\mathbf{x})= & \ln p(y i)-\frac{1}{2} \ln \left|\boldsymbol{\Sigma}_{i}\right|-\frac{1}{2}\left(\mathbf{x}-\boldsymbol{\mu}_{i}\right)^{T} \boldsymbol{\Sigma}_{i}^{-1}\left(\mathbf{x}-\boldsymbol{\mu}_{i}\right) \\
g_{i}(\mathbf{x})= & \ln p(y i)-\frac{1}{2} \ln \left|\boldsymbol{\Sigma}_{i}\right|-\frac{1}{2} \mathbf{x}^{T} \boldsymbol{\Sigma}_{i}^{-1} \mathbf{x}+\mathbf{x}^{T} \boldsymbol{\Sigma}_{i}^{-1} \boldsymbol{\mu}_{i}- \\
& \frac{1}{2} \boldsymbol{\mu}_{i}^{T} \boldsymbol{\Sigma}_{i}^{-1} \boldsymbol{\mu}_{i}
\end{aligned}
$$

Fungsi $g_{i}(\mathbf{x})$ adalah fungsi diskriminan untuk kelas ke- $i$. Suatu piksel akan diklasifikasi ke dalam kelas ke- $i$ berdasarkan nilai $g_{i}(\mathbf{x})$ terbesar (James et al. (2013)).

\section{B. Support Vector Machine}

Support Vector Machine (SVM) adalah salah satu metode klasifkasi terbimbing nonparametrik. Metode SVM dipopulerkan oleh Vapnik dalam bukunya, Statistical Learning Theory. SVM bekerja dengan membuat sebuah bidang pemisah atau hyperplane yang dapat memisahkan data berdasarkan kelasnya. Selanjutnya akan dijelaskan algoritme untuk membuat sebuah hyperplane yang linier (Burges (1998)).

Pada kondisi data yang dapat dipisahkan secara sempurna, fungsi dari hyperplane dapat dinotasikan sebagai berikut:

$$
y_{i}\left(\mathbf{w}^{T} \mathbf{x}_{i}+b\right)-1 \geq 0
$$


dengan:

$y_{i} \quad:$ kelas tutupan lahan ke- $i, y_{i} \in\{-1,1\}$

w : vektor normal terhadap hyperplane

$\mathbf{x}_{i} \quad$ : vektor data training piksel ke- $i, i=1, \ldots n$

$b \quad:$ jarak antara titik pusat dengan hyperplane

Setiap hyperplane memiliki nilai margin sebesar $\frac{2}{\|\mathbf{w}\|}$. Optimal hyperplane didapat dengan memaksimumkan jarak antara hyperplane dengan piksel terdekat dari hyperplane. Margin maksimum didapat dengan meminimumkan $\|\mathbf{w}\|^{2}$ sehingga fungsi objektifnya dapat ditulis sebagai:

$$
\min \left\{\frac{1}{2}\|\mathbf{w}\|^{2}\right\}
$$

dengan kendala

$$
y_{i}\left(\mathbf{w}^{T} \mathbf{x}_{i}+b\right)-1 \geq 0
$$

Masalah optimasi pada persamaan (5) dapat diselesaikan dengan metode Lagrangian. Persamaan Lagrangian yang dapat dibentuk berdasarkan persamaan (5) yaitu:

$$
L P=\frac{1}{2}\|\mathbf{w}\|^{2}-\sum_{i=1}^{n} \alpha_{i}\left(y_{i}\left(\mathbf{x}_{i} \cdot \mathbf{w}+b\right)-1\right), \alpha_{i} \geq 0
$$

$L P$ disebut sebagai Lagrangian Primal Problem, $\alpha_{i}$ adalah koefisien pengali Lagrangian. $L P$ dapat diturunkan terhadap $\mathbf{w}$ dan $b$. Selanjutnya, melalui beberapa operasi aritmatika didapatkan persamaan:

$$
L D=\sum_{i=1}^{n} \alpha_{i}-\frac{1}{2} \sum_{i=1}^{n} \sum_{j=1}^{n} \alpha_{i} \alpha_{j} y_{i} y_{j} \mathbf{x}_{i} \cdot \mathbf{x}_{j}
$$

LD disebut sebagai Lagrangian Dual Problem dan $\mathbf{x}_{j}$ adalah vektor training piksel ke- $j$. Melalui $\mathrm{LD}$, nilai $\alpha_{i}$ dari tiap piksel dapat diketahui. Jika suatu piksel memiliki nilai $\alpha_{i}>0$, piksel tersebut disebut sebagai support vector. Support vector adalah piksel yang posisinya terletak di hyperplane dan piksel tersebut menentukan bentuk dari hyperplane. Fungsi disriminan SVM yaitu:

$$
f(x)=\operatorname{sgn}\left(\sum_{i=1}^{n s} \alpha_{i} y_{i} \mathbf{x}_{i}^{T} \mathbf{x}+b\right)
$$

dan $b$ adalah Chang and Lin (2011):

$$
b=-\frac{1}{n s} \sum_{i=1}^{n s} y_{i}\left(\sum_{j=1}^{n s} \alpha_{j} y_{i} y_{j} \mathbf{x}_{i} \cdot \mathbf{x}_{j}-1\right)
$$

dengan:

$\mathbf{x} \quad$ : vektor piksel yang akan ditentukan kelasnya

$\mathbf{x}_{i}, \mathbf{x}_{j}$ : vektor data training piksel ke- $i, j$ yang menjadi support vector

ns : banyaknya data training yang merupakan support vector

Algoritme di atas dapat digunakan untuk data yang terpisah secara sempurna. Ketika kondisi tersebut tidak dipenuhi, peubah $\xi_{i}$, yang disebut sebagai slack variable, ditambahkan ke dalam formulasi SVM. Fungsi objektif pada persamaan (5) menjadi:

$$
\min \left\{\frac{1}{2}\|\mathbf{w}\|^{2}+C \sum_{i} \xi_{i}\right\}
$$

dengan kendala

$$
y_{i}\left(\mathbf{w}^{T} \mathbf{x}_{i}+b\right) \geq 1-\xi_{i}, \xi_{i} \geq 0
$$

Parameter $C$ adalah parameter besarnya penalti akibat kesalahan klasifikasi yang nilainya ditentukan oleh peneliti. Persamaan Lagrangian Primal berdasarkan fungsi objektif di atas yaitu :

$$
\begin{aligned}
L P= & \frac{1}{2}\|\mathbf{w}\|^{2}+C \sum_{i} \xi_{i}-\sum_{i=1}^{n} \alpha_{i}\left(y_{i}\left(\mathbf{x}_{i} \cdot \mathbf{w}+b\right)-1+\xi_{i}\right) \\
& -\mu_{i} \sum_{i} \xi_{i}
\end{aligned}
$$

dengan kendala

$$
\alpha_{i} \geq 0, \xi_{i} \geq 0
$$

Koefisien $\mu_{i}$ merupakan koefisien pengali Lagrangian untuk $\xi_{i}$. LP dapat diturunkan terhadap $\mathbf{w}, b$, dan $\xi_{i}$. Selanjutnya, melalui beberapa operasi aritmatika didapatkan persamaan:

$L D=\sum_{i=1}^{n} \alpha_{i}-\frac{1}{2} \sum_{i=1}^{n} \sum_{j=1}^{n} \alpha_{i} \alpha_{j} y_{i} y_{j} \mathbf{x}_{i} \cdot \mathbf{x}_{j}, 0 \leq \alpha_{i} \leq C$

Jika tidak memungkinkan untuk memisahkan piksel dengan hyperplane yang linier, data terlebih dahulu ditransformasi ke dalam ruang dimensi yang lebih tinggi menggunakan fungsi kernel $K\left(\mathbf{x}_{i}, \mathbf{x}_{j}\right)$. Berdasarkan hasil studi yang dilakukan Kavzoglu and Colkesen (2009) serta Cho et al. (2017), penelitian ini akan memakai fungsi kernel RBF pada metode SVM. Fungsi kernel RBF 
memiliki rumus:

$$
K\left(\mathbf{x}_{i}, \mathbf{x}_{j}\right)=\exp -\gamma\left\|\mathbf{x}_{i}-\mathbf{x}_{j}\right\|^{2}
$$

dengan $\gamma>0$ adalah parameter dari fungsi kernel RBF. Fungsi diskriminan SVM yang menggunakan fungsi kernel yaitu :

$$
f(x)=\operatorname{sgn}\left(\sum_{i=1}^{n s} \alpha_{i} y_{i} K\left(\mathbf{x}_{i}, \mathbf{x}\right)+b\right)
$$

\section{METODE}

\section{A. Data}

Penelitian ini menggunakan data Landsat 8 yang direkam pada tanggal 19 Juli dan 4 Agustus 2017 dengan path/row 122/064 yang diperoleh dari situs USGS LandsatLook (https://landsatlook.usgs. gov). Peubah penjelas pada penelitian ini adalah band 4, 5, dan 6 dengan resolusi $30 \mathrm{~m}$. Peubah respons yang diamati adalah bentuk tutupan lahan yang terdiri atas vegetasi dan nonvegetasi. Unit amatannya adalah piksel. Pemilihan band yang digunakan pada penilitian ini merujuk pada penelitian yang dilakukan oleh Putri (2017). Data penunjang yang digunakan adalah Peta Administrasi Provinsi DKI Jakarta.

\section{B. Prosedur Analisis Data}

Proses analisis data akan menggunakan perangkat lunak $\mathrm{R}$ 3.4.3, dan QGIS 3.03. Langkah-langkah yang dilakukan pada penelitian ini adalah sebagai berikut:

1) Praproses Citra.

a) Melakukan komposit citra untuk mendapatkan tampilan visual citra yang berwarna. Kombinasi band yang digunakan untuk komposit citra yaitu kombinasi 6-5-4.

b) Koreksi Citra

Koreksi citra dilakukan dengan membuat mask untuk tutupan awan menggunakan metode blueband dengan treshold 14000 dan mask untuk bayangan awan. Piksel yang tertutup awan akan diganti dengan piksel pada lokasi yang sama dari data citra Landsat 8 tanggal 4 Agustus 2017. Metode tersebut dilakukan berdasarkan petunjuk penggunaan QGIS yang ditulis oleh L (2016).

c) Melakukan pemotongan citra untuk mendapatkan data citra yang sesuai dengan Peta Administrasi Provinsi DKI Jakarta. Wilayah Kepulauan Seribu tidak dimasukkan ke dalam penelitian karena kondisi tutupan lahan yang menjadi fokus pengamatan adalah tutupan lahan di wilayah perkotaan.

2) Melabelkan data

Tabel I

\begin{tabular}{|c|c|}
\hline Area & Definisi \\
\hline Vegetasi & $\begin{array}{l}\text { Taman kota, taman wisata alam, taman } \\
\text { rekreasi, taman lingkungan perumahan dan } \\
\text { permukiman, taman lingkungan perkan- } \\
\text { toran dan gedung komersial, taman hutan } \\
\text { raya, hutan lindung, kebun binatang, pe- } \\
\text { makaman umum, lahan pertanian, kawasan } \\
\text { jalur hijau, semak dan belukar, lapangan } \\
\text { olahraga, area penyangga lapangan udara }\end{array}$ \\
\hline Nonvegetasi & $\begin{array}{l}\text { Lahan terbuka, permukiman, jaringan jalan, } \\
\text { pelabuhan, danau atau waduk, rawa, kali }\end{array}$ \\
\hline
\end{tabular}

DEFINISI AREA VEGETASI DAN NONVEGETASI

Pelabelan data adalah upaya untuk mempersiapkan data training. Proses pelabelan dilakukan dengan menggunakan analisis gerombol K-means. Gerombol-gerombol yang terbentuk akan digabungkan menjadi gerombol vegetasi dan gerombol nonvegetasi. Setelah itu, sebanyak $1 \%$ piksel dari tiap gerombol akan dipilih secara acak untuk divalidasi menggunakan data historis wilayah Jakarta yang tersedia pada Google Earth sehingga akan didapatkan data piksel yang telah diberi label dengan benar. Definisi vegetasi dan nonvegetasi yang digunakan dalam penelitian ini dapat dilihat pada Tabel I. Definisi tersebut mengacu pada Peraturan Menteri Dalam Negeri Nomor 1 Tahun 2007 dan Standar Klasifikasi Penutupan Lahan yang dikeluarkan oleh Badan Informasi Geospasial. 
3) Menyusun data training dan data testing

Tabel II

ALOKASI BANYAKNYA DATA TRAINING UNTUK KLASIFIKASI

\begin{tabular}{lllllllll}
\hline Kelas & \multicolumn{8}{c}{ Banyaknya piksel per skenario } \\
\hline Vegetasi & 20 & 30 & 50 & 100 & 250 & 500 & 750 & 1000 \\
Nonvegetasi & 20 & 30 & 50 & 100 & 250 & 500 & 750 & 1000 \\
\hline
\end{tabular}

Piksel yang telah melalui proses pelabelan akan digunakan untuk menyusun data training dan data testing. Sebanyak $10 \%$ dari piksel tersebut akan dipilih secara acak untuk menyusun data testing dan $90 \%$ piksel lainnya akan digunakan untuk menyusun data training. Untuk mengetahui pengaruh banyaknya data training yang digunakan terhadap hasil akurasi klasifikasi, banyaknya piksel data training ditentukan dengan skenario yang dijabarkan dalam Tabel II.

4) Melakukan klasifikasi dengan metode QDA dengan menggunakan skenario data training pada Tabel II. Setiap skenario dilakukan sebanyak 100 ulangan.

5) Melakukan klasifikasi dengan metode SVM

Langkah pertama yang dilakukan adalah menentukan parameter $C$ pada persamaan (10) dan $\gamma$ pada persamaan (13) yang akan dipakai untuk setiap skenario data training. Nilai $C$ dan $\gamma$ yang dicobakan yaitu $10^{-9}$, $10^{-6}, 10^{-3}, 10^{0}, 10^{3}$ untuk parameter $\gamma$ dan $10^{-2}, 10^{0}, 10^{2}, 10^{4}, 10^{6}$ untuk paramater $C$ sehingga terdapat 25 kombinasi parameter. Kinerja 25 kombinasi 25 parameter tesebut diukur dengan metode cross validation. Nilai $k$-fold yang digunakan yaitu 10 fold. Proses penentuan parameter diulang $100 \mathrm{kali}$ pada tiap skenario mengingat terdapat 100 set data training untuk tiap skenario. Setiap kombinasi parameter akan menghasikan 100 nilai error pada tiap skenario Kombinasi parameter yang memberikan rata-rata nilai error terkecil pada masing-masing skenario akan digunakan untuk membangun model SVM

6) Mengevaluasi hasil klasifikasi

Hasil kinerja klasifikasi dapat dirangkum dalam bentuk matriks yang disebut sebagai matriks konfusi (Tabel III).

Tabel III

MATRIKS KONFUSI

\begin{tabular}{lcc}
\hline \multirow{2}{*}{ Kelas Hasil Prediksi } & \multicolumn{2}{c}{ Kelas Aktual } \\
\cline { 2 - 3 } & Vegetasi & Nonvegetasi \\
\hline Vegetasi & $\mathrm{A}$ & $\mathrm{B}$ \\
Nonvegetasi & $\mathrm{C}$ & $\mathrm{D}$ \\
\hline
\end{tabular}

dengan:

A : banyaknya piksel vegetasi yang diprekdiksi sebagai vegetasi

B : banyaknya piksel nonvegetasi yang diprediksi sebagai vegetasi

C : banyaknya piksel vegetasi yang diprediksi sebagai nonvegetasi

D : banyaknya piksel nonvegetasi yang diprediksi sebagai nonvegetasi

Matriks tersebut dapat digunakan untuk menghitung nilai overall accuracy, sensitivity, specificity dengan persamaan sebagai berikut:

$$
\begin{aligned}
\text { OverallAccuracy } & =\frac{A+D}{A+B+C+D} \\
\text { Sensitivity } & =\frac{A}{A+C} \\
\text { Specificity } & =\frac{D}{B+D}
\end{aligned}
$$

Berdasarkan persamaan di atas, nilai overall accuracy, sensitivity, specificity memiliki skala 0 sampai 1 . Semakin besar nilainya, semakin baik kinerja klasifikasinya

7) Membandingkan nilai Overall Accuracy, Sensitivity, dan Specificity pada kedua metode

Proses membandingkan nilai-nilai tersebut menggunakan diagram kotak garis. Uji $\mathrm{t}$ digunakan apabila perbedaan nilai kedua metode tidak terlihat pada diagram kotak garis. 
IV. HASIL DAN PEMBAHASAN

\section{A. Praproses Citra}

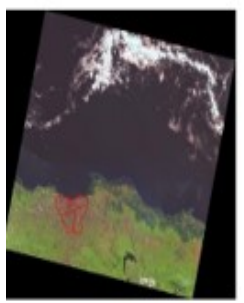

(a)

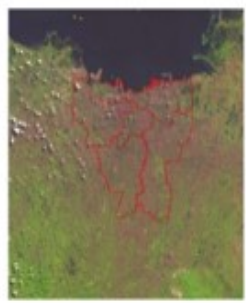

(b)

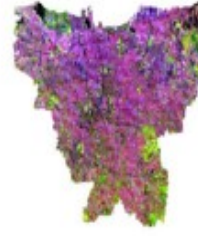

(c)
Gambar 1. Data citra sebelum dan sesudah praproses citra: (a) Data citra hasil komposit citra (b) Area citra yang akan dipotong (c) Data citra sesudah pemotongan citra

Berdasarkan Gambar 1(a), terdapat beberapa daerah tertutup oleh awan dan bayangan, termasuk wilayah Jakarta. Piksel yang tertutup awan dan bayangan ditangani dengan membuat mask untuk awan dengan menggunakan metode blueband serta membuat mask untuk bayangan. Selanjutnya, piksel yang tertutup awan dan banyangan digantikan dengan piksel pada lokasi yang sama dari data citra Landsat tanggal 4 Agustus 2017. Pada akhir praproses, data citra dipotong sesuai dengan Peta Administrasi Provinsi DKI Jakarta. Praproses citra menghasilkan data citra yang terdiri atas 712530 piksel

\section{B. Pelabelan Data}

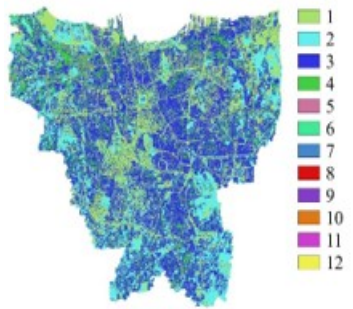

(a)

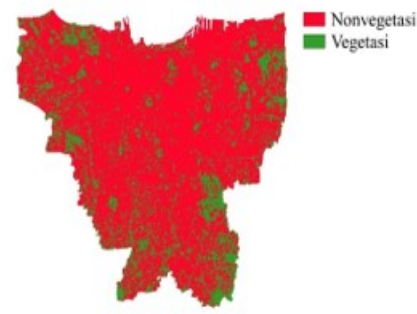

(b)
Gambar 2. Proses penggerombolan dengan k-means: (a) 12 gerombol (b) 2 gerombol

Proses pelabelan data dilakukan dengan bantuan metode penggerombolan $K$-means yang dapat dilihat pada Gambar 2. Penggerombolan dilakukan dengan nilai $k$ yaitu $12,24,36$, dan 48 . Hasil penggerombolan dievaluasi dengan melihat rasio antara total keragaman antar gerombol (BSS) dengan total keragaman dalam gerombol (WSS) dan nilai Calinski-Harabaz $(\mathrm{CH})$ yang ditampilkan dalam Tabel IV.

Tabel IV

HASIL PENGGEROMBOLAN DENGAN K-MEANS

\begin{tabular}{lrr}
\hline Banyaknya $k$ & Rasio WSS dan BSS & \multicolumn{1}{l}{ Nilai CH } \\
\hline 12 & 1.909 & 123690.160 \\
24 & 3.107 & 96262.940 \\
36 & 4.099 & 83449.190 \\
48 & 4.556 & 69073.820 \\
\hline
\end{tabular}

Tabel 4 menunjukkan bahwa semakin banyak nilai $k$, nilai rasio BSS dan WSS semakin kecil. Hal tersebut disebabkan semakin banyak gerombol yang dipakai, total keragaman dalam gerombolnya semakin kecil dan antar gerombolnya semakin besar. Namun, penggerombolan dengan nilai $k=$ 12 menghasilkan nilai $\mathrm{CH}$ terbesar. Nilai tersebut menunjukkan bahwa penggerombolan dengan nilai $k=12$ merupakan penggerombolan yang terbaik. Kedua belas gerombol tersebut digabung menjadi 2 gerombol, yaitu gerombol vegetasi dan gerombol nonvegetasi. Gerombol vegetasi terdiri atas 138649 piksel dan gerombol nonvegetasi terdiri atas 573881 piksel.

Selanjutnya, tiap gerombol diambil piksel secara acak sebanyak 1\% dari banyaknya piksel tiap gerombol, yaitu 1584 piksel vegetasi dan 5937 piksel nonvegetasi. Piksel yang terpilih divalidasi menggunakan data historis wilayah Jakarta tahun 2017. Proses validasi menghasilkan 1632 piksel vegetasi dan 5888 piksel nonvegetasi yang akan digunakan untuk membuat data training dan data testing. Sebanyak $10 \%$ piksel tersebut dipilih secara acak untuk menyusun data testig dan sebanyak $90 \%$ sisanya akan digunakan untuk menyusun data training. Data testing tersusun dari 164 piksel vegetasi dan 589 piksel nonvegetasi

\section{Klasifikasi dengan QDA dan SVM}

Pada proses klasifikasi menggunakan QDA, tidak ada parameter yang nilainya harus ditentukan 
oleh peneliti. Nilai parameter tersebut ditentukan oleh statistik masing-masing data training. Hasil akhir dari proses ini yaitu 800 model QDA yang terdiri atas 100 model untuk tiap skenario.

Proses klasifikasi menggunakan SVM diawali dengan menentukan parameter $C$ dan $\gamma$ yang akan dipakai. Nilai $\gamma$ dan $C$ yang dicobakan yaitu $10^{-9}$, $10^{-6}, 10^{-3}, 10^{0}$, dan $10^{3}$ untuk parameter $\gamma$ dan $10^{-2}, 10^{0}, 10^{2}, 10^{4}$, dan $10^{6}$ untuk parameter $\mathrm{C}$ sehingga terdapat 25 kombinasi parameter. Hasil proses penentuan parameter ditampilkan dalam Tabel V. Kombinasi parameter yang diinginkan yaitu kombinasi yang menghasilkan rata-rata nilai error terkecil pada masing-masing skenario data training. Kombinasi tersebut akan digunakan untuk membuat model SVM untuk setiap set data training. Hasil akhir dari proses ini yaitu 800 model SVM yang terdiri atas 100 model untuk setiap skenario.

Tabel V

KOMBINASI PARAMETER SVM TERPILIH UNTUK SETIAP SKENARIO

\begin{tabular}{lrlll}
\hline Nomor skenario & Banyaknya piksel per kelas & $C$ & $\gamma$ & Error \\
\hline 1 & 20 & $10^{6}$ & $10^{-6}$ & 0.098 \\
2 & 30 & $10^{4}$ & $10^{-3}$ & 0.079 \\
3 & 40 & $10^{6}$ & $10^{-6}$ & 0.085 \\
4 & 100 & $10^{6}$ & $10^{-6}$ & 0.078 \\
5 & 250 & $10^{4}$ & $10^{-3}$ & 0.072 \\
6 & 500 & $10^{0}$ & $10^{0}$ & 0.069 \\
7 & 750 & $10^{0}$ & $10^{0}$ & 0.068 \\
8 & 1000 & $10^{0}$ & $10^{0}$ & 0.066 \\
\hline
\end{tabular}

Hasil kinerja klasifikasi dari metode QDA dan SVM pada 800 set data ditunjukkan pada Gambar 3 sampai dengan Gambar 6.

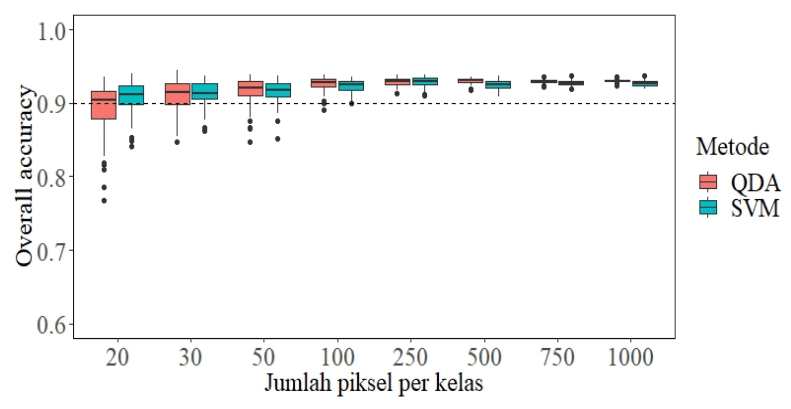

Gambar 3. Diagram kotak garis untuk overall accuracy
Overall accuracy (OA) adalah parameter ketepatan hasil klasifikasi untuk seluruh piksel. Gambar 3 menunjukkan semakin banyak data training yang digunakan, nilai median OA semakin meningkat dan keragaman OA semakin kecil. Secara umum, kedua metode menghasilkan nilai median OA di atas 0.9 untuk setiap skenario. Ketika menggunakan 20 piksel per kelas, nilai median OA metode QDA lebih kecil dari metode SVM. Namun, nilai median OA metode QDA cenderung lebih besar dari metode SVM ketika menggunakan data training sebanyak 30 piksel per kelas atau lebih walau selisihnya kecil. Ketika menggunakan 250 piksel per kelas, nilai median OA metode QDA dan SVM adalah sama. Secara lebih rinci, kedua metode menghasilkan nilai OA di atas 0.9 untuk setiap ulangan ketika menggunakan data training sebanyak 250 piksel per kelas atau lebih.

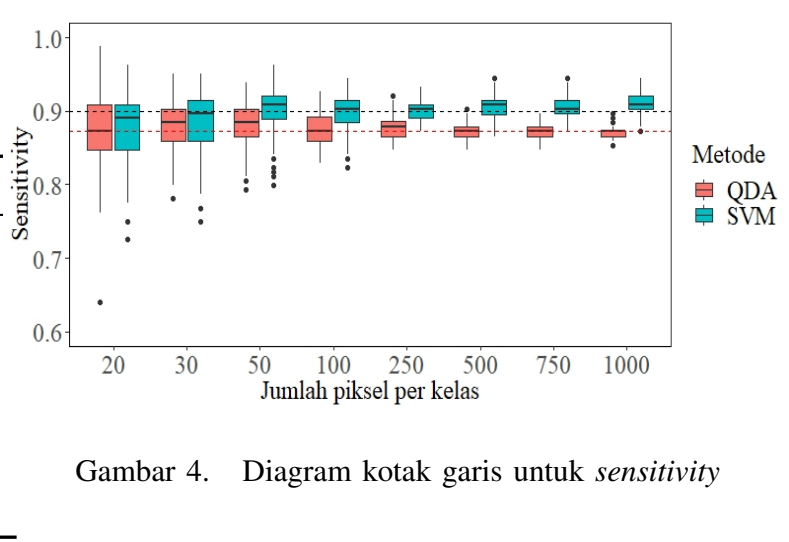

Sensitivity adalah parameter ketepatan hasil klasifikasi untuk piksel kelas vegetasi. Gambar 4 menunjukkan semakin banyak data training yang digunakan, keragaman nilai sensitivity dari kedua metode semakin kecil. Kedua metode menjukkan kinerja yang berbeda pada nilai median sensitivity. Semakin banyak data training yang digunakan, nilai median sensitivity QDA semakin konvergen menuju 0.872 yang ditandai dengan garis berwarna merah pada Gambar 5. Nilai median sensitivity metode SVM cenderung meningkat seiring semakin banyak data training yang digunakan. Secara lebih rinci, nilai median sensitivity metode SVM mencapai 0.9 ketika banyaknya data training yang digunakan adalah 50 piksel per kelas atau 
lebih.

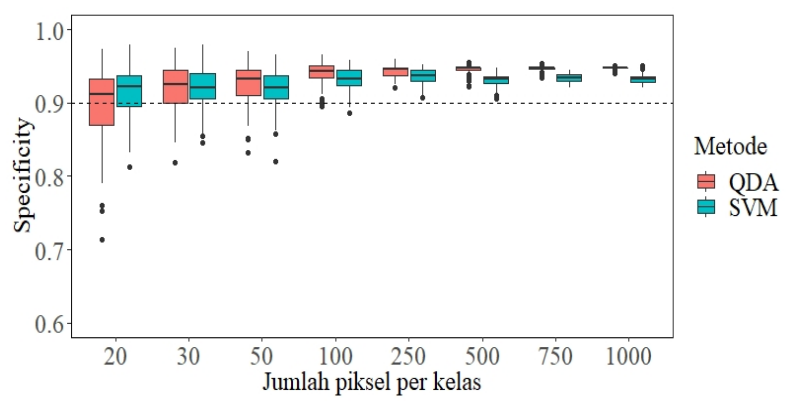

Gambar 5. Diagram kotak garis untuk specificity

Specificity adalah parameter ketepatan hasil klasifikasi untuk piksel kelas nonvegetasi. Gambar 5 menunjukkan semakin banyak data training yang digunakan, nilai median specificity semakin meningkat dan keragaman nilai specificity semakin kecil. Secara umum, kedua metode menghasilkan nilai median specificity di atas 0.9 untuk setiap skenario.Ketika menggunakan 20 piksel per kelas, nilai median specificity metode QDA lebih kecil dari metode SVM. Namun, nilai median specificity metode QDA lebih besar dari metode SVM ketika menggunakan data training sebanyak 30 piksel per kelas atau lebih. Secara lebih rinci, kedua metode menghasilkan nilai specificity di atas 0.9 untuk setiap ulangan ketika menggunakan data training sebanyak 250 piksel per kelas atau lebih.

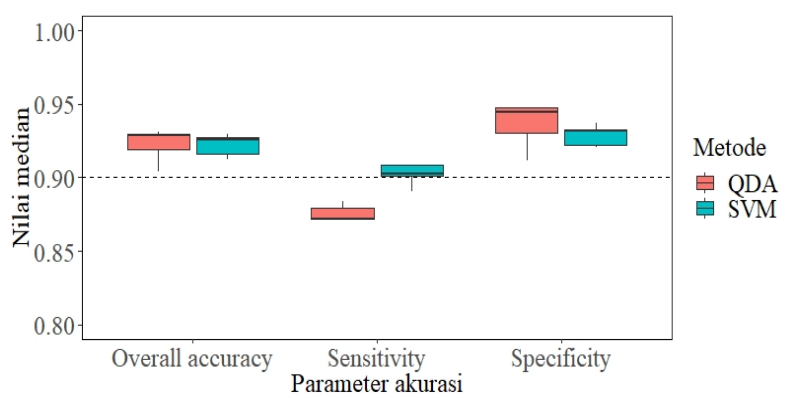

Gambar 6. Diagram kotak garis untuk perbandingan metode QDA dan SVM berdasarkan nilai median tiap skenario

Gambar 6 menunjukkan perbandingan kinerja metode QDA dan SVM pada nilai median overall accuracy, sensitivity dan specificity. Berdasarkan overall accuracy, metode QDA dan svm menunjukkan kinerja yang relatif sama. Kedua metode terlihat menunjukkan kinerja yang berbeda ketika ditinjau berdasarkan sensitivity dan specificity. Metode SVM menunjukkan kinerja sensitivity lebih baik dari metode QDA karena nilai median sensitivity dari metode SVM dapat mencapai 0.9 , sedangkan dari metode QDA tidak mencapai 0.9. Metode QDA menujukkan kinerja specificity lebih baik dari metode SVM karena nilai median specificity dari metode QDA cenderung lebih besar dari metode SVM. Namun, diagram kotak garis specificity SVM terlihat beririsan dengan diagram kotak garis specificity QDA. Oleh karena itu, uji t dilakukan untuk menguji perbedaan kinerja specificity QDA dan SVM. Hipotesis dari uji t adalah $\mathrm{H}_{0}$ : kinerja specificity QDA relatif sama dengan SVM dan $\mathrm{H}_{1}$ : kinerja specificity QDA lebih baik dari SVM. Berdasarkan hasil uji t, didapatkan nilai $t=1.612$ dan nilai $p$-value $=$ 0.068 dengan nilai derajat kebebasan $d f=10.147$. Nilai $p$-value lebih besar dari $\alpha=0.05$ sehingga hasil uji t menunjukkan bahwa kinerja specificity QDA relatif sama dengan SVM. Selain itu Gambar 6 memperlihatkan kedua metode memiliki nilai sensitivity lebih kecil dari nilai specificity. Hal tersebut disebabkan data testing memiliki proporsi yang tak seimbang pada dua kelas.

\section{SIMPULAN}

Hasil penelitian ini menunjukkan semakin banyak data training yang digunakan, keragaman dari overall accuracy, sensitivity dan specificity pada kedua metode semakin kecil. Berdasarkan nilai overall accuracy dan specificity, metode QDA dan SVM memiliki kinerja yang relatif sama. Namun, metode SVM lebih baik daripada QDA berdasarkan nilai sensitivity.

\section{DAFTar Pustaka}

Badan Pusat Statistik Provinsi DKI Jakarta (2017). JAKARTA DALAM ANGKA 2017. Jakarta(ID): Badan Pusat Statistik Provinsi DKI Jakarta.

Burges, C. (1998). A tutorial on support vector machines for pattern recognition. Data Mining and Knowledge Discovery 2(2), 121-167. 
Chang, C. and C. Lin (2011). Libsvm : A library for support vector machines. ACM Transactions on Intelligent Systems and Technology 2(3), 27.

Cho, G., N. Gantulga, and Y. Choi (2017). A comparative study on multi-class svm and kernel function for land cover classification in a kompsat-2 image. KSCE Journal of Civil Engineering 21(5), 1894-1904.

James, G., D. Witten, T. Hastie, and R. Tibshirani (2013). An Introduction to Statistical Learning with Applications in $R$. New York(USA): Springer.

Katadata (2017). Ruang terbuka hijau di jakarta kurang dari 10 persen. [Internet]. [diunduh 2018 April 1]. Tersedia pada: https://databoks.katadata.co.id /datapublish/2017/01/24/jumlah-ruang-terbukahijau-di-jakarta-mencapai-3100.

Kavzoglu, T. and I. Colkesen (2009). Kernel function analysis for support vector machines for land cover classification. International Journal of Applied Earth Observation and Geoinformation 11(5), 352-359.

L, C. (2016). Semi-automatic classification plugin documentation. [Internet]. [diunduh 2018 Oktober 18]. Tersedia pada: https://doi.org/10.1016/j.jag.2009.06.002.

Muhammad, F. (2014). Kajian Beberapa Metode Klasifikasi Citra Digital terhadap Data Penginderaan Jauh [skripsi]. Bogor(ID): Institut Pertanian Bogor.

Noi, P. and M. Kappas (2018). Comparison of random forest, k-nearest neighbor, and support vector machine classifiers for land cover classification using sentinel-2 imagery. Sensors 18(1), 18-19.

Putri, D. (2017). Pemodelan Klasifikasi Tutupan Lahan Gambut Kabupaten Rokan Hilir Provinsi Riau Menggunakan Convolutional Neural Network [skripsi]. Bogor(ID): Institut Pertanian Bogor.

Richards, J. (2012). Remote Sensing and Digital Image Analysis An Introduction. New York(USA): Springer. 